\title{
The Credit-Growth Nexus: New Evidence from Developing and Developed Countries
}

\author{
Sassi Seifallah* - Ben Ali Mohamed Sami
}

\begin{abstract}
The purpose of this paper is to assess the relationship between credit market development and economic growth for a heterogeneous panel of 20 developing and developed countries with varied growth experiences. The empirical study is based on estimations of generalized method of moments $(G M M)$ and pooled mean group (PMG) on heterogeneous panel data model. Difference GMM estimation indicates that credit market development has a negative effect on economic growth. This result is robust for our full sample and for the subsample of non-OECD countries, but not for the subsample of OECD countries. However, using a PMG model, we provide evidence of a positive impact in the long run between credit market development and economic growth. When considering heterogeneity in the short-run relationship across countries, our findings suggest that the credit-growth relationship is specific across countries, depending on each country-specific legal and macroeconomic environment.
\end{abstract}

(J.E.L.: E44, O16, C33, ).

\section{Introduction}

Economic growth has always been a major subject of interest for academicians and policy makers. Although Solow's (1956) exogenous growth theory has been the cornerstone of empirical research on growth, an important strand of the empirical literature on economic growth focused on specifications based on variants of the (augmented) Solow model in which the long-run economic growth depends on the inclusion of accumulation of human as well as physical capital (Mankiw et al., 1992) and endogenous growth models by broadening the definition of capital to include investment in human capital (Schultz, 1980), allowing for learning by doing, counteracts the tendency to diminishing returns in the aggregate or involving research and development (Romer, 1986), foreign direct investment (DeMello, 1999) and Schumpeterian-type models in which capital is an input to the production technology for innovations (Howitt and

*Laboratoire d'économie et Finance Appliquée-IHEC Carthage, Tunisia. E-mail: seifallah. sassi@yahoo.fr

${ }^{\dagger}$ Department of Finance and Economics, College of Business and Economics, Qatar University, Qatar. E-mail: msbenali@qu.edu.qa 
Aghion, 1998). A body of comprehensive empirical macroeconomic literature has also been devoted to the credit-growth nexus since Schumpeter's (1912) precursory economic development theory.

The attempt to theorize the credit-growth nexus originated primarily with Gurley and Shaw's $(1955,1956)$ seminal studies and was later extended and developed by McKinnon (1973) and Shaw (1973) among others. The issue has recently received renewed interest concerning developing and developed economies (Levine, 2005; DeSerres et al., 2006; Beck et al., 2009; Dos Santos, 2011).

When assessing the credit-growth nexus, numerous studies have relied on measures of the size or the structure of the financial system as proxies to assess the relationship between financial system development and economic growth (Levine, 2005; DeSerres et al., 2006). Credit and financial development are therefore closely linked in the literature. In developed countries and mainly in developing countries, credit is by far the largest source of finance for firms (Caviglia et al., 2002). According to endogenous growth theories, credit provided by the banking sector and liquid liabilities in an economy are explanatory variables of a country's economic growth. Meanwhile, as demonstrated in the existing literature, inefficient financial and banking systems can be a significant hindrance to economic growth. By weakening the credit channelling process to investment and slowing its optimal allocation, this factor can bear the risk of bank failure and consequently can hinder economic growth. Notably, when compared to other markets, the banking industry has a specific feature in the sense that the industry acts using an asymmetric information framework. By collecting, monitoring and processing information on investment efficiently and at a lesser cost, banks can decline transaction costs, develop economies of scale and therefore contribute through credit to fulfil the role of economic growth promotion.

On the theoretical level, several previous models described and assessed the positive impact of the credit market on economic growth (Gurley and Shaw, 1955, 1956; Korliras, 1974; Bernanke and Blinder, 1988; Hung and Cothren, 2002; Aghion et al., 2005; Hung, 2009). Overall, these studies support the Schumpeterian point of view that focuses on the product and process innovations of banks to foster economic growth. Conversely, Hayek's (1941) position supports a different point of view, suggesting that credit does not have any stimulating effect on growth and production. This point of view is also shared by Robinson (1952), who states that 'where enterprise leads, finance follows', and Lucas (1988), who considers that economists overstate the role of the financial system in the development process. On an empirical level, the results highlight a rather ambiguous effect of credit market development on economic growth. In fact, some studies suggested that in the stages of development, economic growth decreases as credit markets develop. Moreover, the effect of credit market development on economic growth differs between low-income and high-income countries (Fu-Sheng, 1998). 
Our research attempts to contribute to the empirical literature by explaining the correlation between market credit development and economic growth. Our empirical study is conducted in a heterogeneous dynamic panel data framework by using a polled mean group model and alternative estimation techniques for a sample of 20 developed and developing countries with varied growth experiences.

The remainder of the paper is organized as follows. Section 2 provides an overview of the primary empirical and theoretical studies. Section 3 presents the econometric methodology. Section 4 describes the data. Section 5 discusses the empirical results. Section 6 concludes.

\section{Literature Review}

The literature devoted to the correlation between credit and growth can be subdivided into the following two primary strands: studies supporting a positive correlation between credit development and economic growth and studies that do not support such a relationship or provide evidence regarding the existence of a threshold in the credit-growth causal relationship. Therefore, the empirical literature does not confirm the existence of a consensus in the credit-growth nexus.

Empirical studies investigating the correlation between financial development and economic growth originated with Goldsmith's (1969) study, which included three primary goals. Goldsmith's first goal was to document the way in which financial structure changes as economies grow. The researcher also sought to assess the impact of overall financial development on economic growth. Finally, Goldsmith sought to evaluate whether financial structures influence the pace of economic growth (Demirgiic-Kunt and Levine, 2004). Using a panel of 35 countries over the period 1860-1963, Goldsmith showed a positive correlation between financial system development and economic growth.

Recent empirical studies have made extensive progress in expanding Goldsmith's (1969) analysis and in assessing the credit-growth nexus. These studies offered much bolder consideration by analyzing this issue on different levels as follows: the firm level (Demirguc and Vojislav, 1998), the industry level (Rajan and Zingales, 1998; Wurgler, 2000), and across countries (Levine and Zervos, 1998; Beck et al., 2009) and time-series settings (Beck et al., 2000). Within this framework, King and Levine's (1993) paper was the starting point of an intensive wave of advanced empirical studies on the correlation between financial development and economic growth. Using a sample of 75 developing countries, these researchers' study attempted to overcome one of the limits of Goldsmith's paper. As a proxy to measure financial development, the authors use credit to the private sector as a proportion of domestic credit and credit to the private sector as a proportion of 
GDP. To measure economic performance, King and Levine (1993) use the per capita real GDP growth rate, the growth rate of the physical capital stock, the total factor productivity and the investment rate. These researchers' results show a robust positive correlation in all specifications between financial development indicators and economic development. In a microeconomic framework, Rajan and Zingales (1998) use a panel of 41 countries over the period 1980-1990 to study the link between companies' external financing needs and economic growth. Rajan and Zingales' results provide robust support to suggest that the more important the financing need of a sector is, the more the development of the credit market has an important effect on the sector's value-added growth. Levine and Zervos (1998) empirically investigated the same issue by using instrumental variables on a sample of 42 countries over the period 1976-1993. These researchers find that the initial level of development of the banking market and the capital market's initial level of development have a positive and significant impact on economic growth in the long run. Beck and Levine (2004) examined an extension to the empirical work of Levine and Zervos (1998) by using a system generalized method of moments (GMM) dynamic panel setting. Their results confirm that the development of the credit market and the development of the capital market both independently exert a positive effect on economic growth. By using a broad sample of 74 countries at various levels of development from the period 1960-1995, Levine et al. (2000) show similar results and provide evidence that factor productivity growth is the primary channel through which credit affects economic growth. More recently, Beck et al. (2009) assess the impact of consumption and investment credits on growth. Using data for 47 developed and developing countries over the period 1994-2005, these researchers show that contrary to investment credit, consumption credit does not produce any significant effect on economic growth. These results were recently confirmed in a different sample and period by Dos Santos (2011), who concludes that countries must control consumer credit and direct credit to investment rather than to consumption given these areas' positive effect on growth.

Studies linking credit development to growth suggest that financial development can promote financial services, which will in turn promote economic growth (La Porta et al., 1998; Levine et al., 2000; Leitao, 2010). Examining the relationship between financial development and economic growth for European countries and for Brazil, India, China and Russia, Leitao (2010) reports a positive link between financial development and economic growth. Hassan et al. (2011) report similar results using heterogeneous panel data from low-income and middle-income countries. These researchers' primary findings suggest a positive relationship between financial development and economic growth in developing countries, noting that 'a well-functioning financial system is a necessary but not sufficient condition to reach steady economic growth in developing countries'. 
The first surprising and ambiguous results of the credit effect on economic growth originated primarily with De Gregorio and Guidotti's (1992) study. Their findings support a negative relationship between financial development and economic growth. Using a sample of 98 countries subdivided into three country subsamples according to initial per capita income, the study reveals a negative and significant impact of financial development, measured by domestic credit as a percentage of GDP, on growth when the sample is restricted to Latin America countries. De Gregorio and Guidotti (1992) explain these results by noting the weakened financial system in the Latin America region because of the rapid and uncontrolled financial liberalization process in the mid-1980s and the financial crises which affected Latin America's economies. Ben Ali and Changuel (2009) addressed this issue for the Tunisian financial sector. Also, Fernandez and Galetovic (1994) confirm the same results for OECD countries when they subdivide their sample of 119 countries into two subsamples according to membership in OECD. Although Ram's (1999) study confirms both the negative and positive relationships of the credit market with regard to economic growth, the results indicate a rather weak or negative relationship between financial development and economic growth. Using a sample of 95 countries, Ram (1999) confirms a positive correlation for only 9 developed countries and a negative correlation for 56 countries. Andersen and Tarp (2003) later confirm these findings. Using the same sample as Levine et al. (2000), these researchers show that the positive correlation between credit and growth disappears and becomes negative when the sample is restricted to sub-Saharan Africa and Latin America countries. Similar evidence has been provided by Favara (2003) on a sample of 87 countries over the period 19601998. All these findings show that credit can influence economic growth only in the intermediate stages of financial development. Bolbol et al. (2005) studied the impact of financial development in Egypt on total factor productivity as a proxy for growth over the period 1974-2002. Their results suggest a positive effect of capital market development whereas banking system development has a negative impact on growth from a threshold determined by the level of per capita income.

As highlighted above, studies focusing on the relationship between credit and economic growth reported contradictory results. The relationship is positive in numerous studies but negative in other studies. Patrick (1966) is among the pioneers who analyzed this puzzling causal relationship. Reporting the existence of a threshold effect in this relationship, Patrick suggests that financial markets stimulate the economic growth of countries in the initial stages of development. The researcher further suggests that when moving from a rudimentary financial sector to a modern one, financial markets improve and become more liquid and less risky and could then foster economic development. Using the assumptions of Gurley and Shaw (1960, 1967), Boyd and Smith (1996) develop a model to explain such a 
relationship. Their results suggest a threshold effect in the financial development-growth nexus. Beginning from this threshold, financial market development leads to endogenous economic growth. Deidda and Fatouh (2002) test the presence of the threshold effects in King and Levine's (1993) sample but their results do not support the positive impact of the credit market above a certain level of per capita GDP. Similarly, Rioja and Valev (2004) show that the impact of financial development on economic growth is negative below a certain threshold and becomes positively significant beginning from this threshold. Greenwood and Smith's (1997) findings support such a result and show that credit market development follows real market development in the initial stages of economic development. The development of the financial markets then induces real growth in the advanced stages of development. To explain such a result, Berthelemy and Varoudakis (1996) indicate that the financial markets can have a persistent negative impact on economic growth in financially repressed environments, primarily in the first stages of economic development. Using the banking development level as the threshold switching variable, these researchers reveal that countries with an initial level of credit market development that is lower than a certain threshold do not benefit from any favourable effects of financial development. To explain the presence of this threshold dynamic, Berthelemy and Varoudakis (1998) re-examined the impact of financial system development on economic growth for a sample of 82 countries over the period 1960-1990. Their results explained this largely widespread threshold effect in literature. Berthelemy and Varoudakis (1998) show that this threshold effect is associated with multiple equilibriums as follows: a 'high path' equilibrium with strong growth amid the normal development of the financial system and a 'low path' equilibrium with low economic growth in which the financial system cannot develop. Between the two equilibriums there is an unstable equilibrium that defines the threshold effect between financial development and economic growth. Beyond this threshold the economy converges to the 'high path' equilibrium, whereas below this threshold the economy remains blocked in a poverty trap.

\section{Methodology}

To examine the effect of credit on economic growth, our empirical framework considers a dynamic growth model:

$$
\begin{gathered}
G D P_{i t}=\alpha_{0}+\alpha_{1} G D P_{i t-1}+\alpha_{2} C P S_{i t}+\gamma X_{i t}+\varepsilon_{i t} \\
\varepsilon_{i t}=\mu_{i}+v_{t}+v_{i t}
\end{gathered}
$$


where ' $G D P$ ' is the logarithm of real gross domestic product, ' $C P S$ ' is the logarithm of credit to the private sector as a percentage of GDP. $X_{i t}$ is a vector of conditioning variables that includes the rate of trade openness measured by the logarithm of the sum of the imports and exports as percentage of GDP 'OPEN', the logarithm of the governmental spending as a percentage of GDP ' $G S$ ', and the annual inflation rate ' $I N F$ '. $\varepsilon_{i t}$ is a general disturbance, including a country-specific unobservable effect, $\mu_{i}$, a time-specific factor $v_{t}$ and an idiosyncratic disturbance $v_{i t}$.

Using different specifications and estimation techniques, we aim to empirically examine the relationship between credit markets and economic growth for a sample of developing and developed countries. First, we apply the difference GMM estimator proposed by Arellano and Bond (1991) on the first-difference transform of equation (1):

$$
\Delta G D P_{i t}=\beta_{1} \Delta G D P_{i t-1}+\beta_{2} \Delta C P S_{i t}+\gamma^{\prime} \Delta X_{i t}+\varepsilon_{i t}
$$

This estimator takes the first difference for each period in order to remove the specific country effect. Under the assumption that the error $\varepsilon_{i t}$ is serially uncorrelated, valid instruments for the equation in first difference are levels of the series lagged at least two periods. The difference GMM estimates can be based on either a one-step or a two-step estimator. In the one-step estimator, the error term $\varepsilon_{i t}$ is assumed to be independent and homoskedastic across countries and time. In the two-step estimator, the residuals of the first step are used to consistently estimate the variancecovariance matrix of the residuals, relaxing the homoskedasticity assumption. So, the two-step estimator is asymptotically more efficient than that obtained in the first step estimator. Although, in the two-step difference GMM, we adopt Windmeijer (2005) small sample robust correction which makes a finite-sample adjustment for the two-step covariance matrix.

An important step that is relevant to the estimation of our model is to conduct M2, Sargan and Kleibergen-Paap tests. The M2-test checks problem regarding the second-order serial autocorrelation of the error terms. The Sargan test verifies that the instruments used are not correlated with the residuals. The Kleibergen-Paap test of under-identification provides statistics for weak instruments test.

Second, as a robustness check, we check whether the results of GMM estimates change across sub-samples. We subdivide the sample into two subsamples: OECD countries and non-OECD countries.

Third, we assume that the behaviour of $G D P_{i t}$ can be represented by an autoregressive-distributed lag (ARDL) model. We consider an ARDL $(1,1,0)$ dynamic panel specification:

$$
G D P_{i t}=\beta_{0}+\beta_{1} G D P_{i t-1}+\beta_{2} C P S_{i t}+\beta_{3} C P S_{i t-1}+\beta_{4} X_{i t}+\varepsilon_{i t}
$$


We apply the pooled mean group (PMG) model developed by Pesaran et al. (1999) on a reparameterization form of equation (4):

$$
\Delta G D P_{i t}=\phi_{i}\left(G D P_{i t-1}+\theta_{0 i}-\theta_{1 i} C P S_{i t-1}\right)+\theta_{2 i} \Delta C P S_{i t}+\theta_{3 i} X_{i t}+\varepsilon_{i t}
$$

where the first term of the equation between parentheses stands for the longrun relationship between the following two variables: credit to the private sector and the GDP. This relationship is stable over time. Credit to the private sector in term of variation is expected to exert short-run effects. In the short run, each country can deviate from the stable log-run relationship between parentheses. $\phi_{i}$ is a negative adjustment coefficient for each country in the sample that is expected to express the restoring force to the long-run state.

Thus, the PMG technique jointly estimates the long-run and the shortrun relationships for dynamic heterogeneous panels through the ARDL model. The merit of this technique is to consider the long-run homogeneity of coefficients against their short-run heterogeneity. This technique also takes into account specific differences and individual country dynamics. Pesaran et al. (1999) indicated that if the ARDL model is stable, then the error correction parameter $\phi_{i}$ will have a negative sign and the long-run coefficients between $G D P$ and $C P S$ will be the same for all countries.

One issue that is relevant to the estimation of the PMG model is the analysis of our variables' order of integration using a panel data unit root test (Im et al., 2003) (IPS) and the detection of the existence of a co-integration relationship using a panel co-integration test (Pedroni, 1997). Pedroni's test takes into account the heterogeneity of individuals in terms of co-integration relationships and the level of short-term dynamics. This relationship then could vary across countries.

\section{Data}

Our dataset is a balanced sample of 20 heterogeneous countries with varied growth experiences. Appendix A shows the countries included in the sample. The data cover the period from 1960 to 2009 and are extracted from the WDI-World Bank database. We use the GDP annual growth rate (growth) as a measure of economic growth. The set of independent variables includes conventional growth determinants. We measure trade openness (OPEN) by the sum of exports and imports to GDP. Trade openness is expected to exert a positive effect on growth given that openness facilitates the exchange of goods and improves capital allocation efficiency (Ben Mim and Ben Ali, 2012). We use government spending (GS) to control for the effect of fiscal policy on economic growth. GS is expected to foster economic development and therefore create economic growth. Meanwhile, GS may have deleterious negative long-run effects on growth. We therefore 
expect both a positive and a negative relationship between growth and GS. We use credit provided to the private sector (CPS) in a percentage of GDP as a proxy for financial development. As documented in the literature review section, recent theoretical and empirical studies provide support regarding both the positive and negative effects of financial development on growth. In our model, we also include the inflation rate (INF) as a control variable.

Tables C. 1 and C. 2 in Appendix C report the descriptive statistics and the pairwise correlation coefficients for all variables, respectively. The descriptive statistics show an average rate of economic growth of approximately 4 percent for all the 20 studied countries. The minimum and maximum growth rates are -19.68 and 34.3 percent for Algeria in 1962 and 1963, respectively. Regarding the total credit to the private sector, the highest ratio is recorded for Iceland (319 percent) whereas Saudi Arabia records the lowest ratio (2.8 percent). The highest inflation rate (3057 percent) corresponds to the hyperinflation that Argentina experienced in 1989.

The majority of the results in the correlation matrix are consistent with theory. The conditional convergence theory predicts that countries with a lower initial GDP level are more likely to grow faster than countries with a high initial GDP. The empirical literature supports a negative effect of inflation on growth, primarily in the long run. The effect of GS on economic growth is ambiguous depending on which type of spending is considered. Whereas GS in investment and infrastructure is likely to improve economic growth, other types of public spending may reduce growth (Kneller et al., 1999). Openness is expected to be positively correlated to growth. By facilitating the exchange of goods and services and by improving capital allocation efficiency, openness can foster economic growth (Ben Mim and Ben Ali, 2012). Regarding the credit indicator (CPS), the correlation matrix suggests a positive correlation to GDP but a negative correlation to the GDP growth rate. Macroeconomic indicators have the expected correlation sign with economic growth as follows: inflation and per capita GDP growth rate are negatively correlated with GS and positively correlated with openness.

Table 1 reports the outcomes of a panel-data unit root estimation based on the IPS test. The results indicate that the unit root null hypothesis is not rejected at the 5 percent significance level for the $G D P$, credit to the private sector $(C S P)$, Trade openness $(O P E N)$ and governmental spending $(G S)$. However, the null hypothesis is rejected for the inflation rate. Thus, control variables can be introduced in the first difference.

\section{Results and Discussion}

\subsection{The Difference GMM Estimator}

The results from estimating equation (3) are reported in Table 2. Difference GMM regressions for overall sample are reported in columns (1) 
124 Economic Notes 2-2014: Review of Banking, Finance and Monetary Economics

Table 1: Panel-Data Unit Root Test (IPS, 2003)

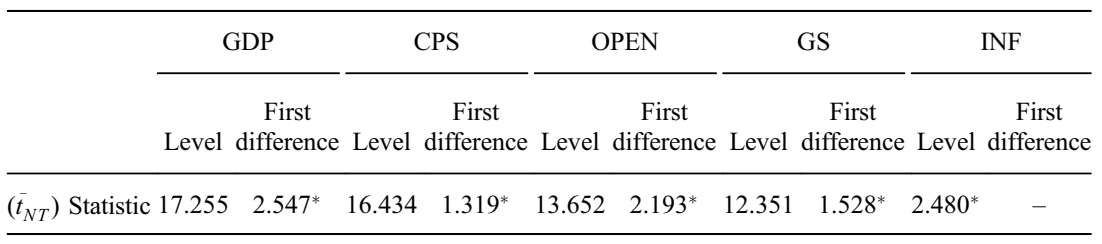

Note: ${ }^{*}$ The non-stationarity null hypothesis is rejected at the 5 percent significance level.

and (2). The one-step and two-step difference GMM estimation show a negative and significant correlation between financial and real spheres. These results are consistent with the findings of Levine et al. (2000), Favara (2003), Ben Naceur and Ghazouani (2007) and Arcand et al. (2012). The results support the negative effect of credit market development on economic growth, suggesting that large and complex financial systems have negative consequences on GDP growth and increase the probability of a 'catastrophic meltdown' as suggested by Rajan (2005) and Arcand et al. (2012). Along with this idea, Minsky (1974), Kindleberger (1978) and Gennaioli et al. (2013) indicate that financial development may lead to an

Table 2: Credit Market Development and Economic Growth

\begin{tabular}{|c|c|c|c|c|c|c|}
\hline \multirow[b]{3}{*}{ Regressions } & \multicolumn{2}{|c|}{ Full sample } & \multicolumn{2}{|c|}{ OECD subsample } & \multicolumn{2}{|c|}{ Non-OECD subsample } \\
\hline & $\begin{array}{l}\text { One-step } \\
\text { difference } \\
\text { GMM }\end{array}$ & $\begin{array}{l}\text { Two-step } \\
\text { difference } \\
\text { GMM }\end{array}$ & $\begin{array}{l}\text { One-step } \\
\text { difference } \\
\text { GMM }\end{array}$ & $\begin{array}{l}\text { Two-step } \\
\text { difference } \\
\text { GMM }\end{array}$ & $\begin{array}{l}\text { One-step } \\
\text { difference } \\
\text { GMM }\end{array}$ & $\begin{array}{l}\text { Two-step } \\
\text { difference } \\
\text { GMM }\end{array}$ \\
\hline & (1) & (2) & (3) & (4) & (5) & (6) \\
\hline$\Delta G D P_{i t-1}$ & $\begin{array}{l}0.821^{* * *} \\
(4.40)\end{array}$ & $\begin{array}{l}0.748^{* * *} \\
(4.86)\end{array}$ & $\begin{array}{l}0.911^{* * *} \\
(3.89)\end{array}$ & $\begin{array}{l}0.871^{* * *} \\
(4.91)\end{array}$ & $\begin{array}{l}0.768^{* * *} \\
(5.06)\end{array}$ & $\begin{array}{l}0.703^{* * *} \\
(6.32)\end{array}$ \\
\hline$\Delta \mathrm{CPS}_{i t}$ & $\begin{array}{l}-0.0016^{* * *} \\
(-2.63)\end{array}$ & $\begin{array}{l}-0.0030^{* *} \\
(-2.29)\end{array}$ & $\begin{array}{l}-0.0043 \\
(-1.47)\end{array}$ & $\begin{array}{l}-0.0048^{*} \\
(-1.74)\end{array}$ & $\begin{array}{l}-0.0025^{* * *} \\
(-2.78)\end{array}$ & $\begin{array}{l}-0.0033^{* * *} \\
(-3.27)\end{array}$ \\
\hline$\Delta$ Trade $_{i t}$ & $\begin{array}{l}0.0063^{* *} \\
(2.10)\end{array}$ & $\begin{array}{l}0.0062^{* * *} \\
(2.66)\end{array}$ & $\begin{array}{l}0.0044^{*} \\
(1.72)\end{array}$ & $\begin{array}{l}0.0058^{*} \\
(1.89)\end{array}$ & $\begin{array}{l}0.0101^{* *} \\
(2.12)\end{array}$ & $\begin{array}{l}0.0099^{* * *} \\
(2.75)\end{array}$ \\
\hline$\Delta G S_{i t}$ & $\begin{array}{l}-0.0141^{*} \\
(-1.83)\end{array}$ & $\begin{array}{l}-0.0125^{*} \\
(-1.76)\end{array}$ & $\begin{array}{l}-0.0195 \\
(-1.13)\end{array}$ & $\begin{array}{l}-0.0154 \\
(-1.62)\end{array}$ & $\begin{array}{l}-0.0121^{*} \\
(-1.72)\end{array}$ & $\begin{array}{l}-0.0169^{*} \\
(-1.87)\end{array}$ \\
\hline$\Delta I N F_{i t}$ & $\begin{array}{l}-0.00000^{* * *} \\
(-3.04)\end{array}$ & $\begin{array}{l}-0.00002^{* * *} \\
(-2.82)\end{array}$ & $\begin{array}{l}-0.00001^{* *} \\
(-2.25)\end{array}$ & $\begin{array}{l}-0.00000^{* *} \\
(-2.13)\end{array}$ & $\begin{array}{l}-0.00000^{* *} \\
(-2.14)\end{array}$ & $\begin{array}{l}-0.00002^{* * *} \\
(-2.76)\end{array}$ \\
\hline Wald test & 0.000 & 0.000 & 0.000 & 0.000 & 0.000 & 0.000 \\
\hline M2 test & 0.612 & 0.582 & 0.753 & 0.568 & 0.608 & 0.631 \\
\hline Sargan test & 0.037 & 0.045 & 0.011 & 0.001 & 0.019 & 0.008 \\
\hline Kleibergen-Paap test & 0.0166 & 0.0166 & 0.0344 & 0.0344 & 0.0087 & 0.0087 \\
\hline No. of countries & 20 & 20 & 9 & 9 & 11 & 11 \\
\hline No. of observations & 905 & 905 & 412 & 412 & 493 & 493 \\
\hline
\end{tabular}

Note: $t$-Student statistics are reported in parentheses. ${ }^{* * *},{ }^{* *}$, and ${ }^{*}$ indicate significance levels at 1,5 , and 10 percent, respectively. For the M2 test for autocorrelation, the null hypothesis is that the errors in the firstdifference regression exhibit no second-order serial correlation. For Sargan test, the null hypothesis is that the instruments used are not correlated with the residuals. For the Kleibergen-Paap test of underidentification, the null hypothesis is that the instruments used are potentially weak. For Wald test, M2 test, Sargan test, and the Kleibergen-Paap test the p-values are reported. 
increase in financial and macroeconomic fragilities and volatilities and can therefore hinder economic growth.

The M2 test confirms the absence of a second-order serial correlation of the residuals in the differenced regression. The Sargan test confirms no correlation between the used instruments and the residuals. In addition, the Kleibergen-Paap test does not detect any problem regarding underidentification restrictions and confirms the validity of variables in difference and in levels as instruments in a difference GMM. Therefore, all tests show that our estimations are robust.

Furthermore, control variables indicated the expected sign. Trade openness has a positive and significant effect on economic growth at least at 10 percent significance level. This finding is consistent with the documented evidence in Sachs and Warner (1995), Dollar and Kraay (2004); and Chang et al. (2009), supporting a positive relationship between openness and economic growth. With regard to inflation, the estimation outcomes report a negative and statistically significant correlation with economic growth at 1 percent significance level in two specifications. This result confirms the findings in the empirical literature. On the one hand, economies tend to have higher growth rates when accompanied by low or moderate inflation levels. On the other hand, countries with high levels of inflation are more likely to have slower growth rates.

\subsection{Robustness Check}

In this section, we subdivide the sample into two sub-samples: OECD countries $^{1}$ and non-OECD countries ${ }^{2}$ to check whether the results of difference GMM estimates change across sub-samples. Columns (3) and (4) in Table 1 report difference GMM results for the OECD countries subsample. Estimates for the subsample of non-OECD countries are presented in Columns (5) and (6).

The results suggest that the signs of the controls are consistently the same while the estimated effects of credit market on growth are sensitive across subsamples. The negative effect of credit market on economic growth deeply proved for non-OECD countries. However, we find no robust evidence of a significant relationship between credit-growth nexus for OECD countries. Our findings are in line with Fernandez and Galetovic (1994). They subdivide the sample of King and Levine (1993) into two subsamples (OECD countries and non-OECD countries) and find that the relationship between finance and economic growth decreases and becomes non-significant for OECD countries.

\footnotetext{
${ }^{1}$ Canada, Chile, Denmark, Iceland, Japan, Sweden, Switzerland, Turkey and United States. and Tunisia.

${ }^{2}$ Argentina, Algeria, Brazil, Egypt, India, Saudi Arabia, South Africa, Syria, Thailand, Togo
} 
Table 3: Panel Co-integration Tests

\begin{tabular}{lcc}
\hline & Group-PP statistic $\left(\bar{Z}_{p p}\right)$ & Group-ADF statistic $\left(\bar{Z}_{\downarrow} t\right)$ \\
\hline Coefficient & $-39.74^{*}$ & $-2,117^{*}$ \\
Significance level & -15.69 & $-1,645$ \\
\hline
\end{tabular}

Note: *A rejection of the null hypothesis of the absence of co-integration at the 5 percent significance level.

\subsection{The Pooled Mean Group Estimator}

One issue that is relevant to the estimation of the PMG model is the check of the existence of a co-integration relationship using a panel co-integration test. Therefore, we test the existence of a co-integration relationship using the Pedroni (1997) panel approach. This test takes into account the heterogeneity of individuals in terms of co-integrating relationships and short-term dynamics. Table 3 presents the outcomes of Pedroni's (1997) test. The null hypothesis of Pedroni's (1997) test assumes the absence of co-integration for all considered countries. The results show the existence of a co-integration relationship in our countries sample between credit market development and economic growth. This result allows us to use the co-integration panel to examine the effect of credit market development on long-term economic growth.

The 'PMG' estimator implies that the long-term relationship is common to all countries in the sample, whereas the dynamic adjustment is specific to each country. Indeed, in the PMG framework, the long-run coefficients are the same for the entire sample but a change in the short-run dynamics is allowed in the adjustment towards the long term.

PMG estimation outcomes for the credit-growth nexus are reported in Table 4 for the entire sample. Table 5 presents the short-term relationship for each country.

The regression results of the PMG equation are presented in Table 4. The results show a positive long-run relationship between credit to the private sector and the GDP growth of the entire sample. Therefore, the credit market plays a fundamental role in the long-run process of economic development. This finding supports the theory that capital accumulation and factor productivity growth have a stimulating effect on growth. This result is consistent with the empirical standard findings that emerge from the growth literature supporting the positive relationship between financial development and economic growth (La Porta et al., 1998; Levine et al., 2000; Rioja and Valev, 2004; Levine, 2005; Leitao, 2010).

The estimation also shows that the correction coefficient error $\phi$ is negative and significant, suggesting the existence of a causal relationship between credit market development and economic growth for all countries. 
Table 4: PMG Estimates for the Overall Sample Dependent Variable: Real GDP

\begin{tabular}{llr}
\hline The overall long-term relationship & CPS & 0.0117 \\
The overall short-term relationship & & $(2.51)^{* *}$ \\
& Error term & $\left(-5.310^{* * *}\right.$ \\
& & $-0.059^{* * *}$ \\
& CPS & $(-3.71)$ \\
& GS & $-0.158^{* * *}$ \\
& INF & $-4.18)$ \\
& & $\left(-2.001^{* *}\right.$ \\
& Constant & $-1.541^{* * *}$ \\
& & $(-2.98)$ \\
\hline
\end{tabular}

Note: $t$-Student statistics are reported in parentheses. ${ }^{* *},{ }^{* *}$, and ${ }^{*}$ indicate significance levels at 1,5 , and 10 percent, respectively.

This result also indicates the existence of a correction mechanism that leads to the convergence of all paths to the long-run target GDP. This finding is supported by Schumpeter's economic development theory and consistent with the recent empirical literature (Aghion et al., 2005; Baltagi et al., 2009).

One important finding from our study is that the positive effect of credit market development on economic growth is recorded for only seven countries in our sample, namely Argentina, Brazil, Chile, Denmark, Thailand, Turkey and the United States. Credit market development does not have a significant short-term effect on economic growth in 12 of our study's 13 remaining countries. These results are consistent with the documented evidence in Andersen and Tarp (2003), Favara (2003), Loayza and Ranciere (2006) and Ben Naceur and Ghazouani (2007), which supported a negative effect or an absence of any long-run effect but a negative short-run effect of economic growth for the majority of the countries in their samples. These findings support Hayek's (1941) pioneer argument that credit markets do not have a stimulating positive effect on growth and production. This viewpoint is also shared by Lucas (1988), who suggests that some economists have overstated the role of the financial system in the development process.

Our results also indicate that the credit market's short-run impact on economic growth is significant and negative for Saudi Arabia. This result suggests that credit market development negatively influences the short-run real development in Saudi Arabia and that this effect becomes positive when development switches to the long run. These ambiguous findings may be explained by the Dutch disease theory. Theoretically, an oil boom generates significant cash flow that could promote financial markets, which would in turn spur economic growth. Yet, paradoxically, the exploitation of hydrocarbons tends to weaken financial institutions because of poor governance and a volatile economic environment. Two-thirds of the world's poor live in countries that are rich in natural resources. 
128 Economic Notes 2-2014: Review of Banking, Finance and Monetary Economics

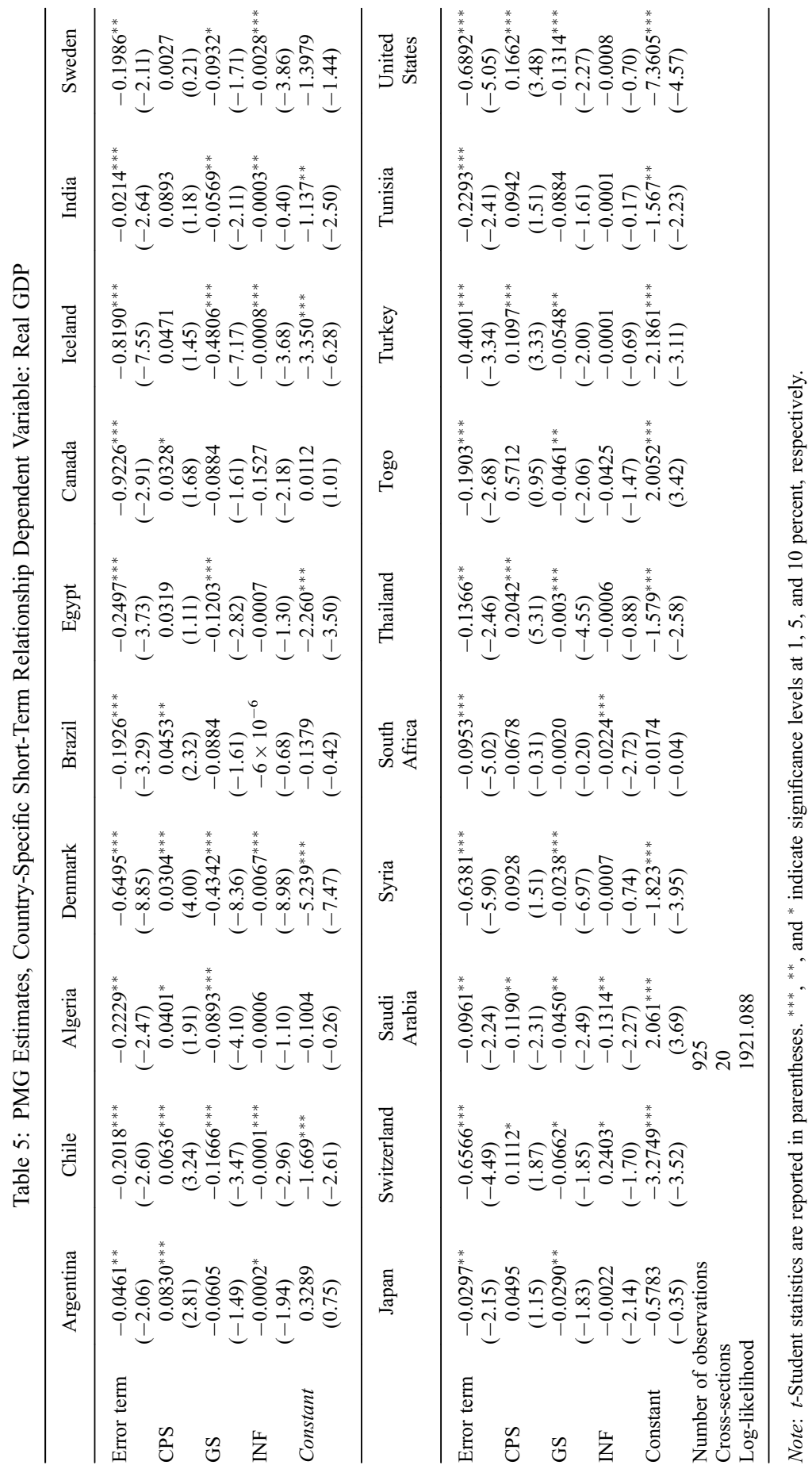

(C) 2014 Banca Monte dei Paschi di Siena SpA. 
Our empirical findings show that inflation and GS have negative effects on economic growth. These results are consistent with the documented evidence in studies by Andersen and Tarp (2003), Favara (2003), Loayza and Ranciere (2006) and Ben Naceur and Ghazouani (2007), supporting the positive long-run impact of credit market development on growth and the negative short-run effect for the majority of the countries in their samples. These results have been widely discussed in the existing literature.

\section{Conclusions}

Our paper examined the credit-growth nexus for a sample of 20 developing and developed countries over the period of 1960-2009. To test the long-run and short-run relationships between credit market development and economic growth, we use two estimations techniques: the GMM method and the PMG estimator. Difference GMM estimation outcomes indicate a negative short-run effect of credit market development on economic growth for the entire sample and for the subsample of non-OECD countries but not for OECD countries. Our findings, in line with Fernandez and Galetovic (1994), Ram (1999) and Favara (2003), suggest that credit-growth nexus is heterogonous and vary at different stages of development.

We proposed an examination of whether this causality in the short term is heterogeneous across countries. Thus, we conducted a PMG estimation for our sample. The estimation outcomes demonstrated that credit market development has a positive long-run effect on GDP growth for the entire sample. This finding suggests that credit must be allocated to long-run productive investments and governments should support credit market development by avoiding credit rationing and interest rate control. However, the detailed short-run PMG results indicated that the credit-growth relationship is heterogeneous across countries which suggest that the credit-growth relationship is specific across countries, depending on each country-specific legal and macroeconomic environment. 


\section{REFERENCES}

P. Aghion - P. Howitt - D. Mayer-Foulkes (2005), "The Effect of Financial Development on Convergence: Theory and Evidence", Quarterly Journal of Economics, 120(1), pp. 173-222.

T. ANDERSEN - F. TARP (2003), "Financial Liberalization, Financial Development and Economic Growth in LDCs", Journal of International Development, 15(2), pp. 189-209.

J.-L. Arcand - E. Berkes - U. Panizza (2012), “Too Much Finance?” IMF Working Paper No. 161.

M. Arellano - S. Bond (1991), "Some Tests of Specification for Panel Data: Monte Carlo Evidence and an Application to Employment Equations", Review of Economic Studies, 58(2), pp. 277-97.

B. Baltagi - D. PAnicos - L. Siong (2009), "Financial Development and Openness: Evidence from Panel Data", Journal of Development Economics, 89(2), pp. 285-96.

T. BeCK - R. Levine (2004), "Stock Markets, Banks and Growth: Panel Evidence”, Journal of Banking and Finance, 28(3), pp. 423-42.

T. BECK - R. LEVINE - N. LoAyzA (2000), "Finance and the Sources of Growth", Journal of Financial Economics, 58(1), pp. 26-30.

T. Beck - B. BüyüKKarabacaK - F. Rioja - N. Valev (2009), "Who Gets the Credit? And Does It Matter? Household vs. Firm Lending across Countries", The World Bank Policy Research Working Paper No. 4661.

M.-S. Ben Ali - M.-B. Changuel (2009), "Financial Liberalization and Banking Fragility within Tunisian Financial Sector", International Journal of Business and Management Science, 2(2): pp. 161-76.

S. Ben Mim - M.-S. Ben Ali (2012), "Through Which Channels Can Remittances Spur Economic Growth in MENA Countries?" International Journal of Economic Perspectives, 6(3), pp. 20-42.

S. Ben Naceur - S. Ghazouani (2007), "Stock Markets, Banks and Growth in Some MENA Region Countries", Research in International Business and Finance, 21(2), pp. 297-315.

B. S. Bernanke - A. Blinder (1988), "Credit, Money, and Aggregate Demand", American Economic Review, 78(2), pp. 435-9.

J. C. Berthelemy - A. Varoudakis (1996), "Economic Growth, Convergence Clubs, and the Role of Financial Development", Oxford Economic Papers, 48(2), pp. 300-28.

J. C. Berthelemy - A. Varoudakis (1998), "Développement Financier, Réformes Financières et Croissance: une Approche en Données de Panel", Revue Economique, 49(1), pp. 195-206.

A. Bolbol - A. Fatheldin - M. OmRan (2005), "Financial Development, Structure, and Economic Growth: The Case of Egypt 1974-2002", Research in International Business and Finance, 19(1), pp. 171-94. 
J. Boyd - B. Sмiтн (1996), "The Coevolution of the Real and Financial Sectors in the Growth Process", The World Bank Economic Review, 10(2), pp. 371-96.

G. Caviglia - G. Krause - C. Thimann (2002), "Key Features of the Financial Sectors in EU Accession Countries", in C. Thimann (ed.), Financial Sectors in Transition Countries, Frankfurt: European Central Bank.

R. Chang - L. Kaltani - N. V. Loayza (2009), "Openness Can Be Good for Growth: The Role of Policy Complementarities", Journal of Development Economics, 90, pp. 33-49.

J. De Gregorio - P. Guidotti (1992), "Financial Development and Economic Growth". IMF Working Papers, 92/101.

L. R. DeMello (1999), "Foreign Direct Investment-Led Growth: Evidence from Time Series and Panel Data", Oxford Economic Papers, 51, Oxford: Oxford University Press, pp. 133-51.

A. Demirgilc-Kunt - R. Levine (2004), Financial Structure and Economic Growth: Perspectives and Lessons, Cambridge, MA: The MIT Press.

K. A. Demirguc - M. Vojislav (1998), "Law, Finance, and Firm Growth”, Journal of Finance, 53(6), pp. 2107-37.

A. S. DeSerres - T. Kobayakawa - L. Sløk - L. Vartia (2006), "Regulation of Financial Systems and Economic Growth", OECD Economics Department Working Papers No. 506.

D. Dollar - A. KraAy (2004), "Trade, Growth and Poverty", The Economic Journal, 114(493), pp. 22-49.

P. Dos Santos (2011), "Production and Consumption Credit in a Continuous-Time Model of the Circuit of Capital", Metroeconomica, 62(4), pp. 729-58.

G. FAVARA (2003), “An Empirical Reassessment of the Relationship between Financial Development and Economic Growth", IMF Working Paper, 03/123.

D. Fernandez - A. Galetovic (1994), "Schumpeter Might Be Right—But Why? Explaining the Relation between Finance, Development, and Growth", Johns Hopkins University SAIS Working Paper in International Economics, No. 9601.

H. Fu-Sheng (1998), "Essays on Financial Market Development and Economic Growth", Dissertation Submitted to the Faculty of Virginia Polytechnic Institute and State University in Partial Fulfillment of the Requirements for the Degree of Ph.D.

N. Gennaioli - R. La Porta - F. Lopez-de-Silanes - A. Shleifer (2013), "Growth in Regions", NBER Working Paper No. 18937.

R. W. Goldsmith (1969), Financial Structure and Development, New Haven, CT: Yale University Press.

J. Greenwood - B. Smith (1997), "Financial Markets in Development, and the Development of Financial Markets", Journal of Economic Dynamics and Control, 21(1), pp. 145-81.

J. G. Gurley - E. S. Shaw (1955), "Financial Aspect of Economic Development", American Economic Review, 45(4), pp. 515-38.

J. G. Gurley - E. S. Shaw (1956), "Financial Intermediaries and the SavingInvestment Process", Journal of Finance, 11(2), pp. 257-76. 
J. G. Gurley - E. S. Shaw (1960), "La Monnaie dans une Théorie des Actifs Financiers", Traduit par le Centre de Traductions Economiques de Perpignan, Edition Cujas, 1974.

J. G. Gurley - E. S. Shaw (1967), "Financial Structure and Economic Development", Economic Development and Cultural Change, 15(3), pp. 257-67.

M.-K. HASSAN - B. SANChEZ - S.-J. Yu (2011), "Financial Development and Economic Growth: New Evidence from Panel Data", The Quarterly Review of Economic and Finance, 51, pp. 88-104.

F. HAYeK (1941), The Pure Theory of Capital, Chicago: University of Chicago Press.

P. Howitt - P. Aghion (1998), "Capital Accumulation and Innovation as Complementary Factors in Long-Run Growth", Journal of Economic Growth, 3, pp. 111-30.

F.-S. Hung (2009), "Explaining the Nonlinear Effects of Financial Development on Economic Growth," Journal of Economics, 97(1), pp. 41-65.

F.-S. Hung - R. Cothren (2002), "Credit Market Development and Economic Growth", Journal of Economics and Business, 54(2), pp. 219-37.

K. S. Im - M. H. Pesaran - Y. Shin (2003), "Testing for Unit Roots in Heterogeneous Panels", Journal of Econometrics, 115(1), pp. 53-74.

C. P. Kindleberger (1978), Manias, Panics, and Crashes-A History of Financial Crises, New York: Palgrave Macmillan.

R. G. KInG - R. Levine (1993), "Financial Intermediation and Economic Development", in C. Mayer - X. Vives (eds) Capital Markets and Financial Intermediation, London: CEPR, Cambridge University Press, pp. 156-89.

R. Kneller - M. Bleaney - N. Gemmell (1999), "Fiscal Policy and Growth: Evidence from OECD Countries", Journal of Public Economics, 74(2), pp. 171-90.

P. G. Korliras (1974), “A Model of Money, Credit, and Economic Growth”, Kyklos, 27(4), pp. 757-76.

R. La Porta - F. Lopez-de-Silanes - A. Shleifer - R. Vishny (1998), "Law and Finance", Journal of Political Economy, 106(6), pp. 1113-50.

N. C. Leitao (2010), "Financial Development and Economic Growth: A Panel Data Approach", Theoretical and Applied Economics, XVII 5(511), pp. 15-24.

R. Levine (2005), "Finance and Growth: Theory and Evidence", in P. Aghion - S. Durlauf(eds), Handbook of Economic Growth. Vol. 1, Chapter 12 Amsterdam: North-Holland, Elsevier, pp. 865-34.

R. Levine - S. Zervos (1998), "Stock Markets, Banks, and Economic Growth", American Economic Review, 88(3), pp. 537-58.

R. LeVINE - N. LoAyza - T. BeCK (2000), "Financial Intermediation and Growth: Causality and Causes", Journal of Monetary Economics, 46(1), pp. 31-77.

N. V. LoAyza - R. Ranciere (2006), "Financial Development, Financial Fragility, and Growth", Journal of Money, Credit and Banking, 38(4), pp. 1051-76.

R. E. Lucas (1988), "On the Mechanics of Economic Development", Journal of Monetary Economics, 22(1), pp. 3-42.

N. G. Mankiw - D. Romer - D. N. Weil (1992), "A Contribution to the Empirics of Economic Growth”, Quarterly Journal of Economics, 107, pp. 408-37. 
R. McKinnon (1973), Money and Capital in Economic Development, Washington, DC: Brookings Institution.

H. P. Minsky (1974), “The Modeling of Financial Instability: An Introduction”, Modeling and Simulation, 5, Part 1, pp. 267-72. Reprinted in Compendium of Major Issues in Bank Regulation, Washington DC: US Government Printing Office (1975), pp. 354-64.

H. T. PAtrick (1966), "Financial Development and Economic Growth in Underdeveloped Countries", Economic Development and Cultural Change, 14(2), pp. 174-89.

P. Pedroni (1997), "Panel Cointegration, Asymptotic and Finite Sample Properties of Pooled Time Series Tests With an Application to the PPP Hypothesis: New Results", Working Paper in Economics, Indiana University.

M. H. Pesaran - Y. Shin - R. P. Smith (1999), "Pooled Mean Group Estimation of Dynamic Heterogeneous Panels", Journal of the American Statistical Association, 94(446), pp. 621-34.

R.-G. RAJAN (2005), “Has Financial Development Made the World Riskier?” NBER Working Paper No. 11728.

G. RAJAN - L. Zingales (1998), "Financial Dependence and Growth", American Economic Review, 88(3), pp. 559-86.

R. RAM (1999), "Financial Development and Economic Growth: Additional Evidence", Journal of Development Studies, 35(4), pp. 164-74.

F. Rioja - N. Valev (2004), "Does One Size Fit All? A Reexamination of the Finance and Growth Relationship", Journal of Development Economics, 74(2), pp. 429-47.

J. Robinson (1952), The Rate of Interest and Other Essays, London: Macmillan Edition.

P. Romer (1986), “Increasing Returns and Long-Run Growth", Journal of Political Economy, 94(5), pp. 1002-37.

J. D. SACHS - A. M. WARner (1995), "Natural Resource Abundance and Economic Growth", NBER Working Papers No. 5398 (National Bureau of Economic Research).

T. W. Schultz (1980), "Nobel Lecture: The Economics of Being Poor", Journal of Political Economy, 88(4), pp. 639-51.

J. A. Schumpeter (1912), The Theory of Economic Development, Cambridge, MA: Harvard University Press.

E. S. SHAw (1973), Financial Deepening in Economic Development, New York: Oxford University Press.

R. Solow (1956), “A Contribution to the Theory of Economic Growth", Quarterly Journal of Economics, 70(1), pp. 65-94.

F. WindmeIJer (2005), "A Finite Sample Correction for the Variance of Linear Efficient Two-Step GMM Estimators", Journal of Econometrics, 126(1), pp. $25-51$.

J. Wurgler (2000), "Financial Markets and the Allocation of Capital", Journal of Financial Economics, 58(1), pp. 187-214. 


\section{Non-technical Summary}

Our paper examines the credit-growth nexus for a sample of 20 developing and developed countries over the period 1960-2009 to test the long-run and short-run relationships between credit market development and economic growth. Estimation outcomes indicate a negative short-run effect of credit market development on economic growth for the entire sample and for the subsample of non-OECD countries, but not for OECD countries. Our findings suggest that the credit-growth nexus is heterogeneous and varies at different stages of development. We propose an examination of whether this causality in the short term is heterogeneous across countries. The estimation outcomes demonstrate that credit market development has a positive longrun effect on GDP growth for the entire sample. This finding suggests that credit must be allocated to long-run productive investments and that governments should support credit market development by avoiding credit rationing and interest rate control. However, the detailed short-run results indicate that the credit-growth relationship is heterogeneous across countries, which suggests that the credit-growth relationship is specific across countries, depending on each country-specific legal and macroeconomic environment.

\section{Appendix A: Countries List}

\begin{tabular}{lllll}
\hline Argentina & Chile $^{\mathrm{a}}$ & \multicolumn{1}{c}{ India } & \multicolumn{1}{c}{ Sweden $^{\mathrm{a}}$} & \multicolumn{1}{c}{ Togo } \\
\hline Algeria & Denmark $^{\mathrm{a}}$ & Japan $^{\mathrm{a}}$ & Switzerland & \\
Brazil & Egypt & Saudi Arabia & Syria & Tunisia $^{\mathrm{a}}$ \\
Canada $^{\mathrm{a}}$ & Iceland $^{\mathrm{a}}$ & South Africa & Thailand & United States $^{\mathrm{a}}$ \\
\hline
\end{tabular}

Note: ${ }^{\text {a }}$ These countries are included in the OECD subsample.

Appendix B: Definition of Variables

\begin{tabular}{llc}
\hline Variable & \multicolumn{1}{c}{ Definition } & Source \\
\hline GDP & Gross domestic product (constant US\$2005) & WDI \\
CPS & Domestic credit to private sector over GDP & WDI \\
GS & Government final consumption expenditure over GDP & WDI \\
OPEN & Total amount of exports and imports over GDP & WDI \\
INF & Increasing rate of consumer price index over 1-year period & WDI \\
\hline
\end{tabular}




\section{Appendix C: Summary Statistics and Pairwise Correlation Matrix}

Table C.1: Summary Statistics

\begin{tabular}{llllllc}
\hline & Variable & Obs. & Mean & SD & Min. & Max. \\
\hline Growth & $\begin{array}{c}\text { Annual per capita real } \\
\text { GDP growth rate }\end{array}$ & 961 & 4.084 & 4.749 & -19.685 & 34.313 \\
IGDP & $\begin{array}{c}\text { Initial per capita GDP } \\
\text { (constant US\$2000) }\end{array}$ & 981 & $5.8 \times 10^{11}$ & $1.6 \times 10^{12}$ & $2.8 \times 10^{8}$ & $1.17 \times 10^{13}$ \\
CPS & $\begin{array}{c}\text { Domestic credit to } \\
\text { private sector } \\
\text { (\% GDP) }\end{array}$ & 951 & 58.786 & 49.967 & 2.808 & 319.475 \\
GS & $\begin{array}{c}\text { Government spending } \\
\text { (\% GDP) }\end{array}$ & 979 & 51.653 & 26.859 & 5.725 & 150.370 \\
OPEN & $\begin{array}{c}\text { Total exports and } \\
\text { imports (\% GDP) }\end{array}$ & 982 & 15.772 & 5.520 & 2.975 & 35.222 \\
\hline $\begin{array}{l}\text { INF (consumer price } \\
\text { index, \%) }\end{array}$ & 976 & 32.517 & 189.37 & -13.336 & 3057.63 \\
\hline
\end{tabular}

Table C.2: Correlation Matrix

\begin{tabular}{lrrrrrr}
\hline & Growth & IGDP & CPS & OPEN & GS & INF \\
\hline Growth & 1 & & & & & \\
IGDP & $-0.0832^{*}$ & 1 & & & & \\
CPS & $-0.1893^{*}$ & $0.5326^{*}$ & 1 & & & \\
OPEN & $0.0199^{*}$ & $0.3125^{*}$ & 0.1188 & 1 & 1 & \\
GS & $-0.2201^{*}$ & $-0.1786^{*}$ & $0.1748^{*}$ & 0.3006 & 1 \\
INF & $-0.1202^{*}$ & -0.0284 & -0.0297 & -0.1485 & $-0.0798^{*}$ & 1 \\
\hline
\end{tabular}

Note: * significant at the $10 \%$ level. 